\title{
Interpretation of Historical Processes of the Epoch of Amir Temur and Temurids in the Works of Academician Bartold
}

\author{
Madraimov Askariy Abdumajidovich ${ }^{1}$ \\ ${ }^{1}$ Department of History of Peoples Central Asia and Source Studies, Tashkent State Institute of Oriental Studies, \\ Uzbekistan \\ Correspondence: Madraimov Askariy Abdumajidovich. Tel: 99-89-1190-2670 E-mail: askari.madraimov@bk.ru
}

Received: September 27, 2018

Accepted: October 24, $2018 \quad$ Online Published: November 29, 2018

doi:10.5539/ass.v14n12p67

URL: https://doi.org/10.5539/ass.v14n12p67

\begin{abstract}
The article is devoted to interpretation of historical processes of the epoch of Amir Temur and Temurids in the works of Academician Vasily Bartold. It shows the degree of change in the interpretation of historical processes in the scientific heritage of the scientist due to political changes in Russia. A historiographic analysis of the most important works of the scientist dedicated to the history of the epoch of Amir Temur and Temurids shows how views of the scholar changed depending of political and national circumstances.

The enormous scientific legacy of V. Bartold on the study of the epoch of Amir Temur and Temurids has not been completely investigated and published yet. The most important views of V. Bartold, scattered in various publications that have become a bibliographic rarity these days, should be reprinted with the necessary scientific commentaries in the light of the new achievements of oriental studies. All this serve to determine the contribution of the peoples of Central Asia to the world civilization in the time of Amir Temur and Temurids, especially in the fields of culture, science, architecture and fine arts.
\end{abstract}

Keywords: history, historiography, middle ages, history of politics, Central Asia, Turkey, Russian Academy of Sciences, Amir Timur

\section{Introduction}

The history of the epoch of Amir Temur and Temurids is a red thread in all scientific work of V. Bartold. A study of the sources of this period, science continuously continued all his life, created a series of works that were first put on a firm scientific basis for studying this topic.

Scientific activity of the scholar can be divided into two stages:

The first stage - before the Russian Revilution of 1917. During this period the scientist wrote more than 149 scientific works, of which 10 were dedicated to the epoch of Amir Temur and Temurids;

The second stage - from 1917 to 1930, when he published 195 works, and 12 of them are related to this topic (Umnyakov \& Tumanovich, 1976).

One of the first publications of V.Bartold was a review of the book by French professor Leon Cahun, "Introduction a' I'histoire de I'Asie. Turcs et Mongols des origints a' 1405" (1896). In the review, V. Bartold belittles the importance of the Uzbek (Chagatai) language in comparison with Persian (Bartol'd, 1968, pp. 248-249). When L. Cahun in his work writes: "The people of the Transoxan Revival wrote in the Chagatai (classical Uzbek) language ", V.Bartold sees here signs of a pro-Turkic national feeling (Bartol'd, 1968, p. 249). According to V. Bartold, a strictly scientific study of the past of Central Asian could be carried by Russia, for which clarifying the course of history of Central Asia had not only theoretical but also political significance. The territory of Central Asia was at that time within Russian interests, and from the above it can be concluded that when foreign scholars were glorifying or objectively studied Asian history, including the epoch of Amir Temur and Temurids, it was unwelcomed by Russian scholars because of Russian-imperial policy to the colonized territory and peoples (Bartol'd, 1968, p. 251).

In 1897, V.Bartold's article "Hafiz-i Abru and his writings" (Bartol'd, 1973, pp. 74-98) appeared in the collection of articles by students of Professor Baron Victor Romanovich Rosen. This work is interesting because young scholar conducted comparative studies of the works of Hafiz-i Abru. The scholar gives a valuable 
historiographical and source assessment, as an impartial scholar with access to primary sources. At the beginning of the article V. Bartold gives an unbiased assessment of the era of the reign of Amir Temur and Temurids (Bartol'd, 1973, pp. 74-98).

The next work of V. Bartold "Essay on the History of the Semirechye" in the "Memorandum of the Semirechye Regional Statistical Committee for 1898" was written by the order of the Semirechye Regional Statistical Committee. In 1943 the second edition was published, which was reprinted with corrections and additions in 1963 in the "Works" (Umnyakov \& Tumanovich, 1976 p. 38; see also Bartol'd, 1963, pp. 21-106).

The essay holds a description of the history of the Semirechye from ancient times to the middle of the 18th century. This work is one of the early works of the scientist on the basis of the study of historical sources (archaeological and written). B. Bartold himself highly appreciated this work and subsequently referenced to it in his works (Bartol'd, 1968, p. 5).

The scientist used such sources in original as "Zafarname" of Sharaf ad-Din Yazdi, works by Hafiz-i Abru, "Babur-name" of Zahiraddin Muhammad Babur, "Tarihi Rashidi" of Muhammad Haydar Duglat as well as others in English and French translation.

In Chapter VII there is description of Amir Temur's campaigns to Mogulistan (Bartol'd, 1968, pp. 81-84), as well as of history of Semirechye in times of Timurid rulers Shahrukh Mirza, Mirzo Ulugbek, Sultan Abu Said Mirza, Sultan Mahmud Mirza, Umarshayh Mirza (Bartol'd, 1968, pp.84-88), and of diplomacy between the Temurid states and China.

\section{Method}

The approach of the scientist in describing historical events is interesting. V. Bartold in most cases ascertained only historical facts, not touching the cause-effect relations and consequences of the actions of Amir Temur and Temurids. Also, we see here an independent evaluation of scholarly historical information from written sources.

"Turkestan in the era of the Mongol invasion" is truly a fundamental work of VV Bartold. His first part ("Texts") was published in 1898, the second part ("Study") - in 1900 (Umnyakov \& Tumanovich, 1976, p. 38).

Subsequently, scholars of the former Soviet Union noted: "The outstanding qualities of fundamental research were recognized immediately and unconditionally. This work has forever entered the golden fund of Russian and World Oriental studies" (Lunin, 1981, p. 223).

The first part included texts from written sources of the 11th-15th centuries. related to the subject of the study, some were translated by B. Bartold into Russian. This part of the work is directly dependent on the study on Marv by V.Zhukovsky, both in the nature of the material attracted to it, and in the scientific approach to it (Lunin, 1981, p. 21), (Smirnova, 1960, p. 58).

"Texts" contain selected, often very extensive, excerpts from Arabic and Persian works, "at that time known only in manuscripts," which increased the scientific significance of their publication. These sources formed the first and unique collection about Turkestan of the time of invasion of Mongols and became the basis and stimulus for further researches in this direction.

In the second part of the work, V. Bartold tried to answer the questions: "What was the course of the country's history before the Mongols, with which the latter came to Turkestan, how did the country's conquest take place?" At the same time, the account of events limited to 1227 (the death of Genghis Khan), for, in the writer's opinion, subsequent events were related to the history of the Chaghatay state and were subject for separate study.

In his study, the author gave a historiographic material containing a critical review and evaluation of sources on the history of Turkestan from Arab authors - historians and geographers and up to Timurid historians inclusive, reviewed the works on the history of the Turkic and Mongolian tribes of Western European orientalists (Deginia, d'Ossona, G. Hovors, D. Ross, and others).

In the first part, we must pay tribute to the author, he introduced into scientific circulation many valuable written sources, and his preliminary analysis has not lost its relevance today.

The next work is about Bibi-Khanum Mosque in Samarkan. This article was published in 1899 in the newspaper "Russian Turkestan". It was a supplement to a note by N. Veselovsky dedicated to 500 years of existence of a mosque published in the pages of the "Turkestanskie Vedomosti" newspaper.

The article is interesting being a continuation of the work on the sources of the Middle Ages. The scientist in his study used the works of Sharaf ad-din Yazdi in translation, Hafiz Abru and Rui Gonzales de Clavijo. The author gives detailed information about the construction of this monument from "Zafar-name" by Sharaf ad-Din Yazdi. 
The laying of the mosque occurred on 11.05.1399, and the completion time of the building refers to $806 /$ 1403-04, that is, when Amir Timur was still in Iran. Returning to Samarkand in the summer of 1404, Amir Timur inspected the mosque and found the front wall or portal (dargah) too low and short; it was replaced by a new, more extensive and higher one. Bartold wrote, that the proud words of Hafiz Abru that "until the end of the world, despite the alternation of months and years, the drawings can not be erased and the entire building is secured from destruction" (Bartol'd, 1966, pp. 116-118; see also Umnyakov \& Tumanovich, 1976, p. 43), now sound irony. But, how long did the building last, when there were many wars and clashes around it during these 500 years. Bartold himself writes in the article that the first repair was carried out in 1587 (Bartol'd, 1966, p. 118). This is in 183 years. That means, until this moment, this building stood. In the author's conclusions there are both positive and negative evaluation of the creative role of Amir Temur's personality.

In 1903, the work of V Bartold named "Historical and Geographical Review of Iran" was published. This course was introduced into curriculum on the initiative of the scholar in 1901-1902 academic year, to "inform students about the past of Muslim countries, while the state of the history of the East as a science does not yet allow them to offer them a proper historical course, ordinarily presented for university history teaching" (Bartol'd, 1971: 23-196). These lectures were first read by the author to students of the Faculty of Oriental Languages of St. Petersburg University (Bartol'd, 1971, p. 8; see also Umnyakov \& Tumanovich, 1976). In our opinion, this course has not lost its relevance today, especially for the subject "Country studies" (Iran and Afghanistan), but the author's materials must be treated critically, based on the requirements of today. They were reprinted with additions and corrections contained in the notes of V. Bartold., according to the authors of the preface of the collection of "Works", V. VII.

From the author's conclusion we understand that the era of Amir Temur and Temurids played both positive and negative role in the development of the territory of Iran and Afghanistan in the Middle Ages. Khorasan becomes the center of trade and diplomacy in Central Asia.

In 1906, V. Bartold's article "The People's Movement in Samarkand in 1365" (Bartol'd, 1964, pp. 362-379) was published. We must not forget that the article was published in time of the first bourgeois revolution in Russia (1905). The article was delivered at a meeting on the Eastern Department of the Russian Archaeological Society February 24 (March 9), 1905 (Umnyakov \& Tumanovich, 1976, p. 63). With sufficient completeness V. V Bartold presents history of the movement according to the writings of Nizam ad-din Shami, Sharaf ad-Din Yazdi, Muin ad-din Natanzi and Abd al-Razzaq. We see here that the political processes in the Russian Empire influenced the appearance and nature of this work. The article continues the methodology of V. Bartold, who makes a detailed analysis and description of written sources of the epoch of Amir Temur and Temurids, and uses it for "objective" coverage of the historical process.

The scholars's conclusions are not final, and he focuses most of attention on the actions of emirs against sarbadars, rather than on crimes of sarbadars against population of Samarkand that were mentioned by medieval authors (Bartol'd, 1964, pp. 374-375). As we know from the history of the movement in Iran that sarbadars strove for social equality, V. Bartold understood that one should not forget that the medieval authors of were influenced by the surrounding atmosphere and passed events through their subjective vision. This article can be used by modern teachers in teaching the course "Source Studies".

In 1914, V. V. Bartold delivered an article "About the Burial of Timur", in the Eastern Section of the Russian Archaeological Society in St. Petersburg and published it in 1915 in "Notes of the Eastern Branch of the Russian Archaeological Society in St. Petersburg, Petrograd" (Bartol'd, 1964, pp. 423-454; see also Umnyakov \& Tumanovich, 1976, p. 87).

The article attempts to compile and compare all the information, available at that time in written sources, about the burial of Amir Temur and about the construction of the building, which is now the tomb of Amir Temur. The article is interesting in itself. But after the studies of M. Masson and G. Pugachenkova on the architecture of the epoch of Amir Temur and Temurids, the article lost its original relevance and significance.

At the beginning of 1914 the Academy of Sciences of Russia decided to start publishing a series of "Texts on the history of Central Asia", and it was decided first of all to publish those works, manuscripts of which exist only in Russia. The choice of the "The Diary of the Campaign of Timur to India" by Guyas al-Din Ali Yazdi for the first volume in 1915 was due not to the exceptional importance of this work, rather to the fact that this text was already prepared for printing at the time and was at the disposal of the Academy. This work still is important for revealing the history of the epoch of Amir Temur and Temurids. The very preface by V. V. Bartold in this book is a valuable tool for scholars studying the history of Central Asia and India in the Middle Ages. There is given a short description of the source, and is mentioned that historical facts indicate the reliability of information from 
this source and also that Nizam ad-din Shami used the work of Giyas ad-Din Ali Yazdi as the primary source in compiling Zafar-name.

All the above-mentioned works were published before the Russian Revolution of October 1917. As we can see, all works are influenced by the imperial policy of tsarist Russia regarding the history of the colonised territories of Central Asia. Only the article "The People's Movement in Samarkand in 1365" (Bartol'd, 1964, pp. 362-379) has the influence of revolutionary ideas in Russia.

Results of V. Bartold's research on the history and culture of the epoch of Amir Temur and Temurids is mainly presented in his work "Ulugbek and his time" (Bartol'd, 1964, pp. 23-196). This work of V. Bartold, published in 1918, has first place, both in volume and in importance, among scholar's works on the Temurids epoch. It is a monographic essay on life of a prominent scientist and ruler Ulugbek (1394-1449). In 1913 V.Bartold wrote to N.Ostroumov that he collected historical material for an article about Ulugbek, and consequently in 1915 he delivered an article to the Academy of Sciences (History of Temur and Ulugbek, 1996, p. 61).

The names of the chapters itself show that the material is very informative. The scholar is not limited to the political history and culture history of the rule of Ulugbek in Maverannahr, he also gives description of the Chaghatay state and the state of Amir Temur in the first two chapters. In conclusion, he describes the political situation in Central Asia after Ulugbek's death.

According to Yu. Bregel, V. Bartold, tried: "to destroy the fantastic idealistic image of Ulugbek as a pure scolar who turned away from politics and gave all his time to mathematics and astronomy" (Bartol'd, 1964, pp. 25-26).

In a state created by Amir Temur, V. Bartold saw a peculiar combination of Muslim and Turkic-Mongolian culture. According to the scientist, in the long run, Muslim culture subdued nomads, but in Central Asia this process was much slower than in Iran, and met more opposition.

In this work, as well as other works on the history of Central Asia, we see that V. Bartold was interested in researching interaction of two cultural and historical factors: the Turkic-Mongolian statehood, on the one hand, and the Muslim, mainly Persian, culture, on the other.

V. Bartold shows that Ulugbek combined adoption of the Muslim (Arab-Persian) culture and fascination with exact sciences, which reached great development in Iran under the Hulaguides, with fidelity to the Mongolian military-political traditions. Here there is a comprehensive description of the personality and activity of Ulugbek, which depicts him not only as a scientist but also as an "ambitious ruler" who tried to imitate his grandfather Amir Temur in every way - and after the death of his father, tried (albeit unsuccessfully) to unite under his power all the lands of former Amir Temur empire (Bartol'd, 1964, pp. 25-200).

In 1922 V. Bartold published an article in the journal Izvestiya Rossiyskoy Academy of the History of Material Culture, Volume II, entitled "Coins of Ulugbek" (Bartol'd, 1966, pp. 362-364). This article is an addition to the reviewed monograph "Ulugbek and His Time". As a result of the study of coins minted by Ulugbek, the author concluded that "Ulugbek, despite his cultural and scientific interests, was even more a Turk and even more valued the military and political traditions of Amir Temur time than it seemed before" (Bartol'd, 1964, pp. 5-196; see also Davidovich, 1965, pp. 274-300; Rtveladze, 1994, pp. 15-17; History of Uzbekistan, 2017, pp. 85, 192).

From the monograph "Ulugbek and his time" we learn that Herat becomes the center of diplomatic relations between Khorasan and Maverannahr with China, interrupted during the reign of Amir Temur (Bartol'd, 1964, pp. 117-119; see also Rtveladze, 1996, p. 55; History of Uzbekistan, 2017, pp. 137-144; Karimova, 2006, p. 25; Madraimov, 2018, pp. 349-352).

There is also information on the development of culture, science, religion in the state of Mirzo Shahrukh and Mirzo Ulugbek. We see a comparative analysis of scholarly life at the court of Shahrukh and Ulugbek, information that Shahrukh Mirza, according to V. Bartold, was more committed to Muslim traditions than Ulugbek. For example in Herat Mirza Shahrukh strictly monitored that pleasures forbidden by religion were not allowed: wine, debauchery, feasts with music and singing, while they were widely held in Samarkand, where the women of the palace participated in such feasts on a par with men (Bartol'd, 1964, p. 121).

Prior to the defeat in the area near Saganak in 1427 Mirzo Ulugbek achieved all political goals in both nomadic states adjacent to Maverannahr (Bartol'd, 1964, p. 112), to place on the throne his puppets, Burak and Sher-Muhammad-oglan (Shirmuhammad), but these khans justified Mirzo Ulugbek's hopes as little as Tokhtamyshkhan-Amir justified Timur's hopes (Bartol'd, 1964, p. 104).

In the work of V. Bartold, we do not find the answer to the question who is to blame for the defeat of Ulugbek to the uzbek khan Burak (Bartol'd, 1964, p. 112). 
We also read that according to V. Bartold, the historical work "The History of the Four Ulus" was not written by Mirzo Ulugbek himself. His erroneous opinion does not represent any historical value (Bartol'd, 1964, p. 142). This fact was pointed out by the well-known historian, academician B. Akhmedov in the foreword to Mirzo Ulugbek's book "The History of the Four Ulus". He proved that this book was written under the scientific guidance and direct participation of Mirzo Ulugbek (Mirzo Ulugbek. History of four Ulus, 1994).

As a result, we see that $\mathrm{V}$. Bartold gives not only a positive but also a negative evaluation to state activities of Mirzo Ulugbek based on the goals of his work. First of all, he wanted to destroy the fantastic image of Ulugbek created by some European scientists who idealized him.

Now this work of V. Bartold is translated into many languages of the world, although some issues require a critical attitude.

\section{Methodology}

We can also say that during and after the national territorial disengagement in Central Asia, V Bartold made some "biased, custom" work. One of them is the "History of Turkestan" (Bartol'd, 1963, pp. 157-162) - a summary of lectures given by the scholar at the History and Philology Faculty of Turkestan University in the 1920/21 academic year. It was published in 1922 in the second edition of Turkestan State University journal. In a very condensed, extremely rich in facts and a meaningful essay, a review of the history of Central Asia from the sixth to the $19^{\text {th }}$ century is given. The sixth chapter of the work is devoted to the reign of Amir Temur and Temurids. Here V. Bartold gives a characterization of the era till the reign of Sultan Hussein in Herat, based on the sources he used. Here the scientist also expressed his attitude towards Amir Temur. The volume of the chapter is only six pages. Such a reduction of information known to V. Bartold, was most likely caused by the political interests of the society (the leaders of the Bolshevik Party).

Another "custom" (in our opinion) work is a lecture course "The Place of the Caspian Region in the History of the Muslim World" (Bartol'd, 1963, pp. 649-772). This is a course of lectures given by the scholar at the Eastern Faculty of the Azerbaijan State University in 1924 in Baku. In 1925 it was published by the Society for Survey and Study of Azerbaijan.

The author's task was to show when and how the Caspian region was included in the circle of world cultural communication and how the comparative significance of individual cities and regions was changing

In this work we also meet the characteristics of Amir Temur and Temurids, in some part of the 7th lecture and more in 8th lecture. There is information about the characteristics and politics of Amir Temur in the Caspian region. The last (10th) lecture lists sources and literature on the Caspian region.

In the eighth lecture we see information about the struggle of Amir Temur and Khan of the Golden Horde Tokhtamyshkhan. It is interesting, that in the "Works", there were added questions and answers to the listeners of the lecture. The question arises: did these questions actually exist, or were they edited during the preparation for publications? The very questions and answers are very political far-fetched (Bartol'd, 1963, p. 741).

Proceeding from the great merits of V. Bartold for studying the history of the Amir Temur and the Temurids epoch, this tendentious passage about the origin of Amir Temur seems written not by the scientist himself, but is a vivid example of the Bolshevik approach.

Later Professor Ahmat Zaki Validi-Togan specially studied this issue of origins of Amir Temur. Prof. Validi-Togan published a detailed article in Persian in 1955 in the Pakistani city of Lahore (Togan, 1955, pp. 105-113), then it was translated into Turkish by Ismail Aka and published in Turkey in 1972 in a special issue of the journal "History" (Publishing house of the Philological faculty of Istanbul University) (Togan, 1972, pp. 76-84). A. Buriev, an Uzbek historian, also devoted his research to this controversial issue (Ancestors of Amir Timur, 1992).

The author of these lines is also involved in the research on the issue of the origin of Amir Temur, We published articles "The dispute about the origin of the family of Amir Temur" and "The personality of Amir Temur in the works of V. Bartold" (Madraimov, 2010, pp. 165-169; 2017, pp. 190-195).

It is interesting that not much is written about the positive side of the actions of Amir Timur. V. Bartold wrote: "It is interesting that Timur pays attention to the Caspian regions. He cares about restoring life; the channels are renewed, watering is carried out" (Bartol'd, 1963, p. 745). But most of all scholar's writing focuses attention on the negative aspects of actions of Amir Temur (Bartol'd, 1963, p. 746).

We should pay attention to how does V. Bartold characterize the actions of Amir Temur. He wrote: "Thus, the destructive actions of Timur, undoubtedly, had a painful character. In his creative activity, we also see a painful 
desire for effect, the desire at all costs to build a building, so that it could outshine all others by its height, and we see that these grandiose buildings have construction technique much lower than artistic sense. The artistic design was great, and historians say that in the artistic part Timur himself took part, but the technique of construction was so weak that these buildings quickly collapsed, and even during Timur's lifetime it was considered dangerous to make a Friday prayer in the mosque he built immediately after construction" (Bartol'd, 1963, p. 746). It should be noted that V. Bartold did not dare to write so rudely and scornfully about Amir Timur before the Russian Revolution of 1917, and therefore one can assume that his political patrons forced him to write so.

The logical continuation of the above-mentioned work is a report delivered by V.Bartold at a public meeting of the Historical and Ethnographic Section of the Society for the Survey and Study of Azerbaijan, December 12, 1924, in the Baku House of Education, named "A Brief Story of the History of Azerbaijan" (Bartol'd, 1963, pp. 775-783). The report in one paragraph provides information on the actions of Amir Timur in Azerbaijan. The scholar wrote: "Central Asian conqueror Timur also paid attention to Azerbaijan and the Caucasus regions. In 1396, he formed a state for his son Miranshah, extending from Derbent and Baku to Baghdad and from Hamadan to Rum (Asia Minor). In 1401, he dug the channel Barlas (now Gyaur Arch), in 1403, the city of Bailakan was rebuilt. At that time, there was formed a state consisting the Caucasian regions, for the son of Miranshakh, Khalil-Sultan, who was not destined to reign it, since he accompanied Timur during his campaign against China, and after his death he took possession of Samarkand" (Bartol'd, 1963, p. 781).

The work of V. Bartold "Iran. Historical overview" (Bartol'd, 1971, pp. 227-334) was published in 1926 in Tashkent. In this monographic work, written sources in Persian are described. The book also contains an overview of historical literature. The book is the a result of many years of work on primary sources. This book is valuable for studying the history of Central Asian countries, but the main attention of the author is paid to the history, especially the history of the Iranian culture. The book also provides important information on both geography and the ethnography of Iran. It was published by the Eastern Faculty of the Samarkand State University with the material assistance of the Society for the study of Tajikistan and Iranians from abroad.

V. Bartold gives a positive description to the development of historiography in the era of Amir Temur and Temurids. The scholar writes: "The events of the late 14th and early 15th centuries, connected with the formation of the empire of Amir Temur (Tamerlane) and his descendants, contributed to the development of historiography in Persian" (Bartol'd, 1971, p. 297).

As for the work of V. Bartold "History of the cultural life of Turkestan" (Bartol'd, 1963, pp. 167-433), initially, the scholar wanted to write it as a monograph. It was created on behalf of the Permanent Commission for the Study of the Natural Productive Forces of the USSR. The author hints that work is influenced by the current state of society: "It would be possible to speak now of "cultural needs" only in connection with the goals of Soviet construction, to which the writer is not sufficiently dedicated" (Bartol'd, 1963, p. 170).

We can cite the words of V. Bartold from this book: "Timur tried to make his creative activity, expressed in buildings and irrigation works, as astonishing, as his destructive activity. Timur's fascination with Muslim urban culture was evident in the fact that the settlements he built around Samarkand were named after the main cities of the Near East and Egypt: Sultania, Shiraz, Baghdad, Damascus and Misr (Cairo)" (Bartol'd, 1963, p. 266).

Proceeding from the purposes of writing, and the impossibility of V. Bartold to correct or supplement his statements, this work carries both political and national colors, an exaggeration of the merits of the Persians (Tajiks) over the Turks. As the author himself admits: "The essay received the character of a historical survey of the cultural life of the former, pre-revolutionary Turkestan. The connection between the essay and modern life is determined only by the benefit that acquaintance with the past can bring to contemporary figures. How far the essay under such conditions can benefit and deserves publication, let the critics decide" (Bartol'd, 1963, p. 168). At present, this work can be used as a popular scientific literature, without using it in scientific works.

The next work was published in 1927 - "Twelve lectures on the history of the Turkish peoples of Central Asia", first in Turkish, then in German translation of 1935 and in 1945 - in French (Bartol'd, 1968, p. 16; see also Umnyakov \& Tumanovich, 1976, p. 127). The publication of this work became possible with the assistance of the Turkish scholar A. Validov (Validi-Togan) who presented the lecture texts in Turkish for publication. In 1968 they were first translated and published in Russian (Bartol'd, 1968, pp. 19-193; 1993, p. 192).

After the Russian Revolution of 1917 V. Bartold visited some foreign countries with scientific missions. In 1922 he lectured at the University of London, March 27, 1923 at the Royal Anthropological Institute in England, in April 1923 he was a delegate from the Soviet Academy of Sciences at the V International Congress of Historians in Brussels, and in the section of the history of the East he delivered a report on the subject of his work, published in Petrograd in 1922. On his way to England (1923), V. Bartold spoke at a meeting of the Finno-Ugric 
Society (Helsinki) with an overview of the work of Russian scholars on the history of Turkestan (Bartol'd, 1977, pp. 564-580; see also Lunin, 1981, p. 155). In 1926 Bartold visited Turkey, where in Istanbul he gave a course of lectures on the history of the Turks of Central Asia. From all this it is clear that his scientific trips are caused by his great scientific authority.

In this work there is a lot of information about the sources of the epoch of Amir Temur and Temurids. V. Bartold emphasizes that "precisely because of the development of historical works at this time, we know about the events that took place from different sources" (Bartol'd, 1968, p. 166; 1993, p. 161).

In the text of the lecture No. 11. the scientist writes that Amir Temur: "... attracted scientists and artists from all over the world to Samarkand, conducted new canals, built magnificent buildings in Samarkand, generally tried to make with his creative activity no less a strong impression than with destructive one" (Bartol'd, 1968, p. 174; 1993, p. 171). Thus, he refutes his earlier statements. As for his words: "Timur showed concern for the spiritual interests of his Turkish citizens only by building a magnificent building over the grave of the main Turkish Muslim saint, Ahmed Yasevi. There were no other buildings of Timur outside Samarkand and its environs" this is certainly a false statement (Bartol'd, 1993, p. 171). Why did he say this? Most likely, at that time, the attitude towards Amir Temur in Turkey was negative and V. Bartold, showing his own attitude in his own words, thereby became their ally.

Well, how else to understand the words of V. V. Bartold: "To this side of his activity, the Turkish elements of his state had almost nothing to do with. Khorezm was the most Turkish country of Timur's conquered countries; masters from Khorezm built for Timur a magnificent Ak-sarai palace in Shakhrisabz, but in this building, except for the name, apparently there was nothing Turkish, among the inscriptions on the walls there are many Persian verses, but not one of Turkish" (Bartol'd, 1968, p. 174; 1993, p. 171).

When describing Amir Temur, V. Bartold repeats his mistake about the origin of the family of Amir Temur. We must understand that the lecture was read in Turkey. V. Bartold expressed an interested opinion that Amir Temur was more a Mongolian nomad than a Turk.

The next work of V. Bartold is "The History of the Turkish-Mongolian Peoples" (Bartol'd, 1968, pp. 193-229), a summary of lectures given to students of the Kazan Higher Pedagogical Institute in the 1926-27 academic year (Umnyakov \& Tumanovich, 1976, p. 129). The most interesting is that only a few lines about the era of Amir Temur and Temurids are given here: "The Chaghatay state, which reached its highest power under Timur (1370-1405), was conquered by the Uzbeks in time of Timur's descendants; the descendants of Timur, expelled from Turkestan, formed for themselves a new state in India, to where the term Chagatai was transferred" (Bartol'd, 1968, p. 212). It is evident that this work is of purely customary, political nature and national color.

The next work of V. Bartold is a monograph dedicated to the great poet of the Middle Ages, Alisher Navoi, "Mir-Ali-Shir and Political Life" (Bartol'd, 1964, pp. 197-260), which was published in the collection for the 500th Hijri anniversary of the birth of the poet in Leningrad in 1928. In this book, a scientist continued his research, chronologically following the book "Ulugbek and his time." If in that work VV Bartold attempted to destroy the fantastic iconic picture of Ulugbek, in this he tried, on the basis of available primary sources, to replace the fantastic image of Alisher Navoi, created not only by the Eastern but also by the European panegyrists with a more realistic picture (Bartol'd, 1964, p. 200; see also Umnyakov \& Tumanovich, 1976, p. 131).

V. Bartold shared the completely wrong assessment of Alisher Navoi's work as completely imitative; such an assessment was reflected in the words opening the first chapter of "Mir Ali-Shir": "Mir-Ali Shir is perhaps the most brilliant representative of that direction in the literary and in general cultural life of the Turks, which is associated with their complete subordination to the influence of the Persian Muslim culture" (Bartol'd, 1964, p. 9).

At present, studies on the life and work of Alisher Navoi have been carried out by many scholars. Therefore, the work of V. V. Bartold became a monument of a certain tendentious, paniranistic character.

The essay on the history of the Turkmen people was published in 1929, the Turkish translation in 1943, the English translation in 1962 (Bartol'd, 1963, pp. 545-623; see also Umnyakov \& Tumanovich, 1976, pp. 134, 147, 151). In the preface it is said that the essay is a preparatory work and does not contain a complete set of data on the past of the Turkmen people. The author's goal is to provide general information on the history of Turkmen. The scientist himself writes that this work will help in the future continue such research. A considerable number of studies on the history of the Turkmen people have now been published.

In the essay we see that V. Bartold, describing the interaction of Turkmen tribes with Amir Temur and Temurids, 
refers readers to his work "Ulugbek and his time".

In our present study, as far as possible, those works of V.V. Bartold that came out during his lifetime were considered. The author did not aspire to cover all the works of the scholar that were published after the death of the scholar on August 19, 1930.

\section{Results}

In conclusion, we can say that $\mathrm{V}$. Bartold made a definite contribution to the study of the history of the epoch of Amir Temur and Temurids, and that the views and methods of historical coverage of historical processes by $\mathrm{V}$. Bartold changed as a result of deep political and social changes that occurred in his time. V. Bartold's views were influenced by changes in Russian Empire, namely, the bourgeois revolution of 1905 and the October revolution of 1917. With the Bolshevik party coming to power, new opportunities arose in the study of the history of Central Asia, that had both a positive side and negative consequences.

In the course of our study, we revealed the distinctive aspects of the treatment of historical processes, the cause-effect relations of the events described in the epoch in the works of V. Bartold. Based on the information from medieval written sources, known to science at that time, the scholar made historical analysis based on contemporary socio-political situation. So initially V. Bartold was influenced by Russian-imperial colonialist views. Then he was influenced by the Marxist-Leninist ideology. It can be seen that after the October revolution and national territorial delimitation, a political necessity appeared for many publications concerning the history of the small nationalities of the USSR. His last works were time-stamped and prepared by the order of the Soviet government. His works had a certain tendentious, nihilistic, obviously paniranistic character. In our opinion, this is due primarily to the large number of written sources in Persian that the scholar had studied. We also see that the scholar draws the main attention of listeners to those moments of the historical past, which were necessary on the basis of the ideological interests of that time.

\section{Discussion}

In the study and analysis of political, economic and cultural life of the epoch of Amir Temur and Temurids, presented in the works of VV Bartold, we see that the of of the reign of Amir Temur and Temurids in the development of world culture was assessed in different ways. V. Bartold argues that culture in the XV-XVI centuries is built on alien cultural traditions, most of all in Persian and the influence of the Turkic peoples is nothing but the destruction of the local Persian culture. The scholar focuses his attention mainly on the negative aspects of Amir Temur and Temurids.

Speaking about the recommendations, it should be said that V. Bartold's archeographic works on searching and researching written sources have not been sufficiently studied.

The enormous scientific legacy of V. Bartold on the study of the epoch of Amir Temur and Temurids has not been completely investigated and published yet. The most important views of $\mathrm{V}$. Bartold, scattered in various publications that have become a bibliographic rarity these days, should be reprinted with the necessary scientific commentaries in the light of the new achievements of oriental studies. All this serve to determine the contribution of the peoples of Central Asia to the world civilization in the time of Amir Temur and Temurids, especially in the fields of culture, science, architecture and fine arts.

The implementation of scientifically commented publications of V. Bartold's works will provide a rich material for modern researchers studying the history of the epoch of Amir Temur and Temurids.

\section{References}

Ancestors of Amir Timur. (1992). (Selected translations from "Zafar-name" of Sharafaddin Ali Yazdi / translation, foreword and footnotes by A. Buriev). Tashkent.

Askarov, A. (1996). History of Temur and Ulugbek. Toshkent.

Bartold, V. V. (1963). Place of Caspian regions in history of Muslim world (Vol. 2, Part 1). Moscow: Izdatel'stvo Vostochnaya literatura.

Bartold, V. V. (1963). Works (Vol. 2, Part 1). Moscow: Izdatel'stvo Vostochnaya literature.

Bartold, V. V. (1964). On entombment of Timur (Vol. 2, Part 2, pp. 423-454). Moscow: Nauka.

Bartold, V. V. (1964). Peoples movement in Samarkand in 1365 (Vol. 2, Part 2, pp. 362-379). Moscow: Nauka.

Bartold, V. V. (1964). Ulugbek and his time. Works (Vol. 2, Part 2). - Moscow: Nauka.

Bartold, V. V. (1964). Works (Vol. 2, Part 2). Moscow: Nauka. 
Bartold, V. V. (1966). Works (Vol. 4). Moscow: Nauka.

Bartold, V. V. (1968). Works (Vol. 5). Moscow: Nauka.

Bartold, V. V. (1971). Works (Vol. 7). Moscow: Nauka.

Bartold, V. V. (1971). Works (Vol. 7, pp. 23-196). Moscow: Nauka.

Bartold, V. V. (1973). Works (Vol. 8). Moscow.

Bartold, V. V. (1977). Works (Vol. 9, pp. 564-580). Moscow: Nauka.

Bartold, V.V. (1993). Turks: Twelve on history of Turkic nations of Middle Asia. Almaty: Jalyn.

Davidovich, E. A. (1965). Materials for charasteristics of monetary reform of Ulugbek: From history of Ulugbek's epoch. Tashkent: Fan.

Karimova, N. E. (2006). Mutual relations between people of Central Asia and China in XIV-XVII centuries (Doctor thesis). Tashkent.

Livshits, V. A. (1971). Foreword: Bartold V. V. Works (Vol. 7). - Moscow: Nauka.

Lunin, B. V. (1981). Life and works of Academicion V. V. Bartold: Central Asia in domestic oriental studies. Tashkent: Fan.

Madraimov A. A. (2018). Trade and diplomatic relationship between Amir Timur and Timurids states and China. Materials of international scientific practical conference "Uzbekistan - China: Progress in historical-cultural, scientific and economic relations" (pp. 349-352). Tashkent.

Madraimov, A. A. (2017). Personality of Amir Temur in works of Acad. V.V.Bartold. / "Actual questions on historical source study, historiography, methodics of history research". Materials of IX Republic scientific conference (pp. 190-195). TDShI. Toshkent.

Madraimov, A.A. (2010). Dispute on geneology of Amir Timur / Hinstory and culture of Eurasia nations - past, present, future. Materiald of international scientific-practical conference dedicated to 120 anniversart of prominent turkology scholar and public figure Ahmet Zeki Velidi Togan, Stambul 21 may, 2010 (pp. 165-169). Ufa: Gilem.

Rtveladze, E. V. (1994). Coins of Ulugbek. Social sciences in Uzbekistan, 7, 15-17.

Rtveladze, E. V. (1996). Chinese embassies to the court of Amir Temur i Temurids. Social sciences in Uzbekistan, $7(10), 55$.

Rtveladze, E. V., \& Alimova, D. A. (Eds.). (2017). History of Uzbekistan. Epoch of Amir Temur and Temurids. Collektiv monograph. Tashkent: Fan.

Smirnova, O. I. (1960). Place of V. A. Jujovskiy work "Antiquities of Zakaspiyskiy Kray. Ruins of old Merv" in history of researches of Central Asia cities. Esseys on history of Russian oriental studies (Collection 5). Moscow.

Ulugbek, M. (1994). History of four Ulus. Preface, footnotes and edition of B. Ahmedov (Translated from Farsi by B. Ahmedov, N. Norqulov, \& M. Hasanov). Toshkent: Cholpon nashriyoti.

Zaki Validi Togan. (1955). Research of geneology of Amir Timur (pp. 105-113). Ze madjlisi Armugan-i ilmi. Lahor. (Persian)

Zaki Validi Togan. (1972). Research of geneology of Amir Timur. Tarih, 26, 76-84. Stambul. (Turkish).

\section{Copyrights}

Copyright for this article is retained by the author(s), with first publication rights granted to the journal.

This is an open-access article distributed under the terms and conditions of the Creative Commons Attribution license (http://creativecommons.org/licenses/by/4.0/). 